\title{
Analisis Putusan Perkara Sengketa Ekonomi Syariah Nomor 0124/Pdt.G/2017/ PTA.BDG tentang Wanprestasi Akad Pembiayaan Murabahah Nomor: TSM/024/2014 atas Lelang Eksekusi terhadap objek Hak Tanggungan
}

\author{
Hilman Akbar Nurrobbi, ${ }^{2}$ Ramdan Fawzi ${ }^{3}$ Panji Adam \\ Program Studi Hukum Ekonomi Syariah, Fakultas Syariah, Universitas Islam Bandung \\ Jl. Tamansari No. 140116 \\ Hilmanakbar11@gmail.com, Ramdanfawzi@unisba.ac.id, PanjiAdam@unisba.ac.id
}

\begin{abstract}
Abstarct-Sharia Economic Dispute, a dispute between one or more actors of economic activity, the occurrence of the dispute is because one of the parties perform a Default. The Tasikmalaya City Religious Court is a case of breach between Tendi Rahmat as Plaintiff and Ministry of Finance of the Republic of Indonesia $\mathrm{Cq}$ the Directorate General of State Assets and Auction for Regional Office VII DKJN Bandung Office of State Wealth Services and Auction of Tasikmalaya City as Defendant 1, and PT. Bank BNI Syariah Tasik Malaya Branch as Defendant 2.
\end{abstract}

Formulation of the problem: first, how is the Sharia Economic Dispute Case Decision Number 0124/Pdt.G/2017/ PTA.Bdg? Second, how is the Analysis of Sharia Economic Dispute Case Decision Number 0124/Pdt.G/2017/ PTA.Bdg Regarding Murabahah Financing Agreement.

This research uses inductive-deductive qualitative methods. Based on the results of the study, the Legal Basis used by the Judge in the case verdict No.1316 / Pdt.G / 2016 / PA.Tmk at the First Level Court namely the Religious Court of Tasikmalaya City is the Circular of the Supreme Court (SEMA) and Article 224 HIR jo Article 14 paragraph (2) Underwriting Law No.4 of 1996. At the Court of Appeals namely the Bandung High Religious Court with Case Number 0124 / Pdt.G / 2017 / PTA.Bdg is UUHT No. 4 of 1996 and Article 6 of Law Number 4 Year 1996 and Article 14 paragraph 2 of the UUHT. Based on the analysis that the Plaintiff has defaulted on the murabaha financing agreement.

Keywords: Performance, Legal Basis, Court Decision.

Abstrak-Sengketa Ekonomi Syariah, suatu pertentangan antara satu pihak atau lebih pelaku kegiatan ekonomi, terjadinya sengketa tersebut karena salah satu pihak melakukan Wanprestasi. Pengadilan Agama Kota Tasikmalaya adalah kasus Wanprestasi antara Tendi Rahmat sebagai Penggugat dengan Kementrian Keuangan Republik Indonesia Cq Direktorat Jendral Kekayaan Negara dan Lelang Kantor Wilayah VII DKJN Bandung Kantor Pelayanan Kekayaan Negara Dan Lelang Kota Tasikmalaya sebagai Tergugat 1, dan PT. Bank BNI Syariah Cabang Tasik Malaya sebagai Tergugat 2.

\begin{abstract}
Rumusan masalahnya : pertama, bagaimana Putusan Perkara Sengketa Ekonomi Syariah Nomor 0124/Pdt.G/2017/PTA.Bdg ?. Kedua, bagaimana Analisis Putusan Perkara Sengketa Ekonomi Syariah Nomor 0124/Pdt.G/2017/PTA.Bdg Tentang Wanprestasi Akad Pembiayaan Murabahah.
\end{abstract}

Penelitian ini menggunakan metode kualitatif induktifdeduktif. Berdasarkan hasil penelitian, Dasar Hukum yang digunakan Hakim dalam putusan perkara No.1316/Pdt.G/2016/PA.Tmk pada Pengadilan Tingkat Pertama yaitu Pengadilan Agama Kota Tasikmalaya adalah Surat Edaran Mahkamah Agung (SEMA) dan Pasal 224 HIR jo Pasal 14 ayat (2) UU Hak Tanggungan No.4 Tahun 1996. Pada Pengadilan Tingkat Banding yaitu Pengadilan Tinggi Agama Bandung dengan Nomor Perkara 0124/Pdt.G/2017/PTA.Bdg adalah UUHT No 4 Tahun 1996 dan Pasal 6 Undang-Undang Nomor 4 Tahun 1996 serta Pasal 14 ayat 2 UUHT. Berdasarkan analisis bahwa Penggugat telah melakukan wanprestasi atas perjanjian pembiayaan murabahah

Kata Kunci: Wansprestasi, Dasar Hukum, Putusan Pengadilan.

\section{PENDAHULUAN}

Sengketa merupakan conflict atau dispute dapat berbentuk perselisihan atau disagreement on a point of law or fact of interest between two persons, artinya suatu kondisi dimana tidak ada kesepahaman di antara kedua belah pihak. Timbulnya sengketa berawal dari situasi dan kondisi yang menjadikan pihak yang satu merasa dirugikan oleh pihak yang lain. Dalam Ekonomi Syariah sering terjadi sengketa salah satunya Sengketa Ekonomi Syariah. Sengketa Ekonomi Syariah merupakan suatu pertentangan antara satu pihak atau lebih pelaku kegiatan ekonomi, dimana kegiatan ekonomi tersebut berlandaskan pada prinsip-prinsip syariah dan ajaran Hukum Ekonomi Syariah yang ditimbulkan oleh adanya perbedaan pendapat tentang suatu hal yang dapat mengakibatkan adanya sanksi hukum terhadap salah satu pihak yang bersangkutan. Dan 
terjadinya suatu sengketa tersebut karena salah satu pihak melakukan Wanprestasi dan atau melakukan perbuatan malawan hukum sehingga dapat menimbulkan kerugian pada pihak yang lain. Wanprestasi adalah kelalaian pihak Debitor dalam memenuhi prestasi yang telah ditentukan dalam perjanjian.

Salah satu Sengketa Ekonomi Syariah yang terdapat di Pengadilan Agama Tasik Malaya adalah kasus Wanprestasi antara Tendi Rahmat sebagai Penggugat dengan Kementrian Keuangan Republik Indonesia $\mathrm{Cq}$ Direktorat Jendral Kekayaan Negara dan Lelang Kantor Wilayah VII DKJN Bandung Kantor Pelayanan Kekayaan Negara Dan Lelang Tasik Malaya sebagai Tergugat 1, dan PT. Bank BNI Syariah Cabang Tasik Malaya sebagai Tergugat 2. Penggugat sebagai debitur telah melakukan Wanprestasi (cidera janji) dan tidak beritikad baik terhadap akad pembiayaan murabahah nomor: TSM/024/2014/Murabahah Modal Kerja WUS tanggal 26 Maret 2014, karena itu tergugat melakukan penjualan lelang terhadap Hak objek Tangungan berupa: sebidang tanah dan bangunan yang melekat diatasnya, SHM No. 1612/Cipedes a.n Nurlela, luas tanah $194 \mathrm{~m}^{2}$ dan luas bangunan $125 \mathrm{~m}^{2}$, yang terletak di Jalan Bojong Tengah No. 5, Kelurahan Cipedes, Kecamatan Cipedes, Kota Tasikmalaya. Lalu di Pengadilan Agama Tasikmalaya gugatan Penggugat menang dan Tergugat kalah.

Karena tidak puas dengan keputusan Pengadilan Agama Tasikmalaya, Tergugat mengajukan Banding ke Pengadilan Tinggi Agama Bandung, kemudian di Pengadilan Tinggi Agama Bandung ternyata Tergugat menjadi menang dan penggugat menjadi kalah. 1

\section{LANDASAN TEORI}

\section{A. Landasan Hukum Pengadilan Agama}

Berdasarkan Pasal 27 ayat 1 UUD 1945 yang menyatakan bahwa segala warga negara bersamaan kedudukannya di dalam hukum dan pemerintahan dan wajib menjunjung hukum dan pemerintahan itu dengan tanpa terkecuali dapat difahami bahwa Pasal tersebut merupakan jaminan hak konstitusional bagi seluruh masyarakat. Terjaminnya hak-hak warganegara di bidang agama ditetapkan dalam Pasal 29 ayat 2 UUD 1945 yang menyatakan bahwa negara menjamin kemerdekaan tiaptiap penduduk untuk memeluk agamanya masing-masing dan untuk beribadat menurut agama dan kepercayaannya. Atas dasar adanya kekhususan hukum untuk pemeluk agama tertentu itulah diadakan peradilan khusus untuk pemeluk agama Islâm. ${ }^{2}$

Eksistensi peradilan agama di Indonesia menjadi kokoh dan menjadi lembaga mandiri setelah adanya Undang-Undang Nomor 7 Tahun 1989 tentang Peradilan
Agama. ${ }^{3}$ Pasal 1 menyatakan bahwa peradilan agama adalah peradilan bagi orang-orang yang beragama Islâm. Pasal tersebut dipertegas oleh Pasal 2 yang menyatakan bahwa peradilan agama merupakan salah satu pelaksana kekuasaan kehakiman bagi rakyat pencari keadilan yang beragama Islâm mengenai perkara tertentu yang diatur dalam undang-undang.

Pengertian perkara tertentu tersebut dijelaskan dalam Pasal 49 yang menyatakan bahwa pengadilan agama bertugas dan berwenang memeriksa, memutus dan menyelesaikan perkara-perkara di tingkat pertama antara orang-orang yang beragama Islâm di bidang perkawinan, kewarisan, wasiat, hibah, wakaf, sadakah, dan ekonomi syarî'ah.

\section{B. Pengadilan Agama}

Peradilan Agama merupakan salah satu dari 4 (empat) lingkungan peradilan tersebut di atas yang keberadaan diatur lebih lanjut dalam Undang-Undang Nomor 14 Tahun 1970 tentang Pokok-Pokok Kekuasaan kehakiman dan yang terakhir telah diganti dengan Undang-Undang Nomor 4 Tahun 2004 tentang Kekuasaan kehakiman. Undang-undang tersebut merupakan suatu undang-undang yang bersifat organik, sehingga perlu adanya peraturan pelaksanannya. Khususnya untuk pengadilan agama dilakukan pengaturan lebih lanjut dengan Undang-Undang Nomor 7 Tahun 1989 tentang Peradilan Agama. Di dalamnya memuat hukum materiil sekaligus hukum formilnya. ${ }^{4}$

Pengadilan Agama berugas dan berwenang memeriksa, memutus dan menyelesaikan perkara-perkara di tingkat pertama antara orang-orang yang beragama Islam, dibidang : Perkawinan, Waris, Wasiat, Hibah Wakaf, Zakat, Infaq, Shadaqah, Ekonomi Syariah; memberikan keterangan, pertimbangan dan nasehat hukum Islam kepada instansi pemerintah di daerah hukumnya apabila diminta dan memberikan itsbat kesaksian rukyat hilal serta penentuan arah kiblat dan waktu sholat serta tugas dan kewenangan lain yang diberikan oleh atau berdasarkan Undang-undang ${ }^{5}$

\section{Kewenangan Pengadilan Agama}

Ketentuan mengenai kompetensi absolut ${ }^{6}$ peradilan agama yang bersifat umum ditetapkan bahwa peradilan agama adalah salah satu pelaksana kekuasaan kehakiman bagi pencari keadilan yang beragama Islam mengenai perkara perdata tertentu. Sementara dalam UU Nomor 3 Tahun 2006 ditetapkan bahwa peradilan agama adalah salah satu pelaksana kekuasaan kehakiman bagi pencari keadilan yang beragama Islam mengenai perkara tertentu. Perubahan klausul (dari perkara perdata tertentu menjadi 
perkara tertentu) menunjukkan bahwa peradilan agama memiliki potensi untuk memeriksa dan memutus perkara perdata yang lebih luas. $^{7}$

Kompetensi relatif adalah kekuasaan atau kewenangan yang diberikan antara pengadilan dalam lingkungan peradilan yang sama atau kewenangan yang berhubungan dengan wilayah hukum antar Pengadilan Agama. ${ }^{8}$ Guna memudahkan pemahaman pengertian tentang kompentensi relatif maka dibuatlah suatu kalimat pertanyaan, yaitu ke Pengadilan Agama mana perkara itu akan diajukan? Dari pengertian di atas maka pengertian kewenangan relatif adalah kekuasaan atau wewenang yang diberikan kepada pengadilan dalam lingkungan peradilan yang sama jenis dan tingkatan yang berhubungan dengan wilayah hukum Pengadilan dan wilayah tempat tinggal/tempat kediaman atau domisili pihak yang berperkara.

\section{HASIl PENELITIAN DAN ANALISA PEMBAHASAN}

A. Putusan Perkara Sengketa Ekonomi Syariah Tentang Wanprestasi Akad Murabahah di Pengadilan Agama Tasik dan Pembatalan di Pengadilan Tinggi Agama Bandung

Pada perkara Nomor 1316/Pdt.g/2016/PA.Tmk. sebagaimana yang terdapat dalam tuntutan Penggugat di dalam surat gugatannya tertanggal 08 September 2016. Bahwa dalam hal ini Majelis Hakim yang mengadili perkara tersebut memberikan putusan yang pada pokok intinya adalah gugatan Penggugat diterima seluruhnya, karena pada dasarnya Tergugat telah terbukti melakukan pelelangan sepihak tanpa ada izin dari pengadilan. Adapun fasilitas pembiayaan awalnya pada tahun 2012 sebagaimana terdapat pada salinan putusan. Selanjutnya berdasarkan kesepakatan telah di perjanjikan jaminan berupa bidang tanah dan bangunan yang melekat di atasnya, SHM No. 1612/Cipedes a.n. Nurlela, luas tanah $194 \mathrm{~m} 2$ dan luas bangunan $125 \mathrm{~m} 2$, yang terletak di jalan bojong tengah No.5, Kelurahan Cipedes, Kecamatan Cipedes, Kota Tasikmalaya9.

Berdasarkan bukti tertulis yang diajukan oleh Tergugat sebagaimana tersebut di atas, Pengugat mengajukan bukti P.7 dan bukti P.8 berupa akta otentik Sertifikat Hak Milik atas jaminan agunan, tetapi bukti tersebut telah dibantah oleh Penggugat dengan bukti T.2a dan bukti T.2b berupa akta otentik Sertifikat Hak Tanggungan Pertama. Disamping itu, dengan adanya bukti P.2, bukti P.3, bukti P.4, dan bukti P.5 menurut penulis justru hal ini membuktikan bahwa Tergugat tidak melakukan perbuatan melawan hukum melainkan merupakan iktikad baik Tergugat karena telah melakukan pemberitahuan secara tertulis kepada Penggugat berkaitan dengan pendaftaran lelang agunan. Artinya, dalam hal ini bukti tertulis yang diajukan oleh Tergugat tidak menunjukkan adanya unsur unsur perbuatan melawan hukum, sehingga tindakan pendafatran lelang agunan tersebut tidak bertentangan dengan hukum yang mengaturnya. Disamping itu, perbuatan melawan hukum tidak serta merta dapat terjadi ataupun dituduhkan kepada seseorang. Akan tetapi, perbuatan melawan hukum sebagaimana dimaksud mesti memenuhi unsur-unsur berupa ada perbuatan, ada kesalahan, ada kerugian, dan sebab-sebabnya atau alasan bahkan unsur-unsur tersebut haruslah bersifat kumulatif.

Selanjutnya sebagaimana uraian pada bab sebelumnya untuk menyatakan Penggugat telah melakukan wanprestasi, Majelis Hakim mempertimbangkan dengan bukti tertulis yang telah diajukan oleh Tergugat, yaitu Bukti yang berupa akta di bawah tangan, yaitu laporan riwayat pembiayaan antara Penggugat I dengan Tergugat I yang telah memenuhi syarat formal dan isinya telah diakui oleh Penggugat. Selanjutnya bahwa berdasarkan bukti tersebut diketahui Penggugat tidak melaksanakan pembayaran atas kewajiban angsuran. Dan untuk memperkuat pertimbangan tersebut Majelis Hakim mengacu pada ketentuan Pasal 1338 KUHPerdata yang berbunyi ${ }^{10}$ :

"Semua perjanjian yang dibuat secara sah, berlaku sebagai undang-undang bagi mereka yang membuatnya. Suatu perjanjian tidak dapat ditarik kembali selain dengan sepakat kedua belah pihak, atau karena alasan-alasan yang oleh undang-undang dinyatakan cukup untuk itu. Suatu perjanjian harus dilaksanakan dengan itikad baik".

Menurut penulis, jika dilihat dari prosedur dalam menyatakan seseorang telah melakukan wanprestasi mesti melalui dua tahapan, pertama sommatie, yaitu peringatan tertulis yang diberikan oleh kreditur kepada debitur secara resmi melalui pengadilan, somasi ini diatur dalam Pasal 1238 KUHPerdata yang berbunyi:

"Si berhutang adalah lalai, apabila ia dengan surat perintah atau dengan sebuah akta sejenis itu telah dinyatakan lalai, atau demi perikatannya sendiri ialah jika ini menetapkan bahwa si berhutang harus dianggap lalai dengan lewatnya waktu yang ditentukan" dan Pasal 1243 KUHPerdata yang berbunyi :

"Penggantian biaya, kerugian dan bunga karena tak dipenuhinya suatu perikatan mulai diwajibkan, bila debitur walaupun telah dinyatakan lalai, tetap lalai untuk memenuhi perikatan itu, atau jika sesuatu yang harus diberikan atau dilakukannya hanya dapat diberikan atau dilakukannya dalam waktu yang melampaui waktu yang telah ditentukan".

Kedua Ingebreke Stelling, yaitu peringatan kreditur kepada debitur secara tersendiri dan tidak melalui pengadilan. Dalam hal ini Tergugat belum pernah mengeluarkan somasi melainkan dengan pemberian surat peringatan tersendiri hal ini dibuktikan sendiri oleh 
Penggugat dengan bukti P.1 bahwa Tergugat 1 telah melakukan teguran baik secara lisan maupun tertulis yaitu berupa Surat Peringatan tanggal 10 Agustus 2016.

Putusan perkara yang telah di putuskan oleh pengadilan agama Kota Tasikmalaya,penggugat menang atas gugatanya. Bahwa Majelis Hakim Pengadilan Tinggi Agama Bandung setelah membaca, meneliti dan mempelajari dengan seksama berkas banding yang terdiri dari salinan resmi putusan Pengadilan Agama Kota Tasikmalaya nomor:1326/Pdt.G/2016/PA.Tmk tanggal 08 September 2016, Berita Acara Sidang, Surat-surat bukti dan surat-surat lainnya yang berhubungan dengan perkara tersebut.

Hal ini Majelis Hakim yang mengadili perkara tersebut memberikan putusan yang pada pokok intinya adalah membatalkan putusan Pengadilan Agama Kota Tasikmalaya Nomor: 1316/Pdt.G/2016/PA.Tmk tanggal 08 September 2016 Masehi. Artinya, Majelis Hakim yang menangani perkara tersebut menyatakan bahwa Tergugat telah terbukti melakukan tindakan melawan hukum, Sehubungan dengan dinyatakannya Para Pembanding/Para Tergugat telah melakukan Tindakan melawan hukum, Majelis Hakim yang menangani perkara ini mengacu pada ketentuan Surat Edaran Mahkamah Agung (SEMA) Nomor: 07 Tahun 2012 tentang rumusan hukum hasil rapat pleno kamar mahkamah agung sebagai pedoman pelaksanaan tugas bagi pengadilan yang berbunyi: "Bahwa pelelangan objek hak tanggungan yang dilakukan oleh kreditur sendiri (Terlawan II) melalui kantor lelang (Terlawan I), apabila terlelang (pelawan) tidak mau mengosongkan objek yang di lelang,tidak dapat dilakukan pengosongan Berdasarkan Pasal 200 ayat (11) HIR melainkan harus di ajukan gugatan". Sedangkan untuk melunasi semua sisa kewajiban Penggugat I kepada Tergugat I, Majelis Hakim mengacu pada ketentuan Peraturan Mahkamah Agung RI Nomor 2 Tahun 2008 tentang Kompilasi Hukum Ekonomi Syariah pada Bab III Bagian keempat Pasal 36 Pasal 38 Huruf C Tentang Ingkar Janji dan Sanksinya.

Menurut Penulis, memang pada dasarnya tidak didapatkan adanya bukti terhadap adanya Perbuatan Melawan Hukum $(\mathrm{PMH})^{11}$ yang dilakukan oleh pembanding/Tergugat, hal ini berdasarkan unsur-unsur perbuatan melawan hukum yaitu, ada perbuatan, ada kesalahan, ada kerugian, dan sebab-sebabnya atau alasan haruslah bersifat kumulatif dan atas dinyatakannya Pembanding/Penggugat telah melakukan wanprestasi, berdasarkan bentuk-bentuk wanprestasi yaitu, tidak melaksanakan prestasi sama sekali, melaksanakan tetapi tidak tepat waktu atau terlambat dari yang diperjanjikan sebelumnya, melaksanakan tetapi tidak seperti yang diperjanjikan, dan melaksanakan yang menurut perjanjian tidak boleh dilakukan, telah sesuai dengan bukti tertulis yang telah diajukan oleh Tergugat, yaitu Bukti pada Pengadilan Tingkat Pertama yang dari bukti tersebut telah diketahui bahwa Penggugat I tidak melaksanakan pembayaran atas kewajiban angsuran. Di samping itu, dalam sebuah hubungan perikatan antara debitur dengan kreditur merupakan hubungan hukum, maka ini berarti bahwa hak si kreditur itu dijamin oleh hukum (UndangUndang). Hal ini dipertegas lagi berdasarkan ketentuan Pasal 1338 ayat (1) KUHPerdata yang menyatakan bahwa semua persetujuan yang dibuat secara sah berlaku sebagai undang-undang bagi mereka yang membuatnya.

B. Analisis Putusan Perkara Sengketa Ekonomi Syariah Nomor 0124/Pdt.G/2017/Pta.Bdg Tentang Wanprestasi Akad Pembiayaan Murabahah Nomor: Tsm/024/2014 Atas Lelang Eksekusi Terhadap Objek Hak Tanggungan

Bahwa pada Pengadilan Tingkat Banding atas permohonan Para Tergugat putusan Pengadilan Agama Kota Tasikmalaya tersebut telah dibatalkan oleh Pengadilan Tinggi Agama Bandung dengan putusan Nomor: 0124/Pdt.G/2017/PTA.Bdg tanggal 07 Maret 2017.

Dalam hal ini Majelis Hakim yang mengadili perkara tersebut memberikan putusan yang pada pokok intinya adalah menerima permohonan kasasi dari Pemohon Kasasi. Artinya, Majelis Hakim yang menangani perkara tersebut menyatakan bahwa Tergugat tidak terbukti melakukan perbuatan melawan hukum.

Sehubungan karena Para Pemohon Kasasi dapat membuktikan bahwa Para Termohon Kasasi/Para Terbanding/Para Penggugat telah melakukan perbuatan melawan hukum, sebaliknya Para pemohon Kasasi berhasil membuktikan dalil-dalil bantahannya, dimana Para termohon Kasasi terbukti telah melakukan wanprestasi dalam pelaksanaan akad yang telah disepakati. Majelis Hakim yang menangani perkara ini mengacu pada ketentuan Pasal 6 Undang-Undang Nomor 4 Tahun 1996 Tentang Hak tanggungan atas tanah beserta benda-benda yang melekat yang berkaitan dengan tanah, menyatakan "Apabila debitor cedera janji, pemegang hak tanggungan pertama mempunyai hak untuk menjual objek hak tanggungan atas kekuasaan sendiri melalui pelelangan umum serta mengambil pelunasan piutangnya dari hasil penjualan tersebut".

Sedangkan Para Termohon Kasasi yang telah dinyatakan lalai dan harus membayar kerugian yang diderita oleh Pemohon Kasasi, Majelis Hakim mengacu pada ketentuan Peraturan Mahkamah Agung RI Nomor 2 Tahun 2008 tentang Kompilasi Hukum Ekonomi Syariah pada Bab III Bagian Keempat Pasal 36 jo Pasal 38 Huruf c tentang Ingkar Janji dan Sanksinya.

Dalam hal ini, seseorang yang telah melakukan wanprestasi akan mendapatkan akibat hukum atau sanksi yang pada umumnya berupa membayar kerugian yang diderita oleh kreditur, yaitu berupa pembayaran ganti rugi, pembatalan perjanjian, peralihan risiko, dimana benda yang dijanjikan berupa obyek perjanjian, sejak saat tidak terpenuhinya 
kewajiban menjadi tanggung jawab dari debitur, dan membayar biaya perkara, kalau sampai diperkarakan di depan Hakim melalui pengadilan. Hal ini diperjelas dalam Pasal 1276 KUHPerdata terdapat 5 (lima) opsi yang dapat dilakukan oleh kreditur dalam mengahadapi debitur yang wanprestasi, yaitu memenuhi/melaksanakan perjanjian, memenuhi perjanjian disertai keharusan membayar gantu rugi, membayar ganti rugi, membatalkan perjanjian, dan membatalkan perjanjian disertai dengan ganti rugi.150 Akan tetapi, dalam hal ini baik Majelis Hakim pada Pengadilan Tingkat Pertama, Banding, dan Kasasi tidak memberikan keputusan tentang berapa jumlah ganti rugi yang harus dibayarkan oleh Penggugat kepada Tergugat, sehingga menurut penulis hal ini bisa menimbulkan kekosongan hukum.

Pada kasus sengketa ekonomi syariah ini, kesesuaian Pertimbangan Hukum bagi Hakim baik pada Pengadilan Tingkat Pertama dan Banding yang menyatakan bahwa Para Penggugat/Para Terbanding/Para Termohon telah melakukan wanprestasi, sedangkan pada tahap banding Para Tergugat/Para pembanding/Para pemohon banding tidak terbukti telah melakukan perbuatan melawan hukum, dengan kata lain Majelis Hakim yang mengadili perkara tersebut tidak menyalahkan tindakan Para Tergugat/Para Pembanding/ Para Pemohon Kasasi yang melakukan pendaftaran lelang agunan. Hal ini sudah tepat dan benar berdasarkan hukum yang mengatur perihal tersebut, yaitu: Bahwa di dalam ketentuan Fatwa DSN-MUI No.68/DSN MUI/III/2008 Tentang Rahn Tasjily pada bagian kedua ketentuan khusus poin (b) dijelaskan "Penyimpanan barang jaminan dalam bentuk bukti sah kepemilikan atau sertifikat tidak memindahkan kepemilikan barang Murtahin. Dan apabila terjadi wanprestasi atau tidak dapat melunasi utangnya, Marhun dapat dijual paksa/dieksekusi langsung baik malulai lelang atau dijual ke pihak lain sesuai prinsip syariah".

Menurut penulis, bahwa berdasarkan bukti tertulis yang telah diajukan oleh Tergugat, yang berupa akta di bawah tangan, yaitu laporan riwayat pembiayaan antara Penggugat I dengan Tergugat I yang telah memenuhi syarat formal dan isinya telah diakui oleh Penggugat I. Selanjutnya bahwa berdasarkan bukti tersebut diketahui Penggugat I tidak melaksanakan pembayaran atas kewajiban angsuran. Artinya, dalam hal ini Penggugat telah terbukti melakukan wanprestasi, sehingga tindakan Tergugat yang melakukan pendaftaran lelang agunan sudah benar sebagaimana ketentuan dalam fatwa tersebut. Ketentuan ini telah diperjelas pada poin (c) yaitu "Rahin memberikan wewenang kepada Murtahin untuk mengeksekusi barang tersebut apabila terjadi wanprestasi atau tidak dapat melunasi utangnya. Dalam menyikapi keputusa Majelis Hakim baik pada Pada Pengadilan Tingkat Pertama dan Banding yang menyatakan Penggugat terbukti telah melakukan wanprestasi, menurut penulis sudah benar dan tepat. Bahwa di dalam ketentuan hukum yang mengatur perihal tersebut, apabila akad yang sudah tercipta secara sah menurut ketentuan hukum itu tidak dilaksanakan isinya oleh debitur atau dilaksanakan tetapi tidak sebagaimana mestinya, maka debitur telah melakukan kesalahan. Kesalahan tersebut adalah suatu sikap yang bertentangan dengan hak dan kewajiban.

\section{KESIMPULAN}

Hasil penelitian dari pembahasan di atas, maka dapat di tarik simpulan sebagai berikut:

1. Dasar hukum yang digunakan Hakim dalam putusan perkara No.1316/Pdt.G/2016/PA.Tmk pada Pengadilan Tingkat Pertama yaitu Pengadilan Agama Kota Tasikmalaya adalah Surat Edaran Mahkamah Agung (SEMA) dan Pasal 224 HIR jo Pasal 14 ayat (2) UU Hak Tanggungan No.4 Tahun 1996. Pada Pengadilan Tingkat Banding yaitu Pengadilan Tinggi Agama Bandung dengan Nomor Perkara 0124/Pdt.G/2017/PTA.Bdg adalah UUHT No 4 Tahun 1996 dan Pasal 6 UndangUndang Nomor 4 Tahun 1996 serta Pasal 14 ayat 2 UUHT.

2. Berdasarkan analisis bahwa Penggugat telah melakukan wanprestasi atas suatu perjanjian pembiayaan murabahah dengan jaminan sebidang tanah dan bangunan yang dimana Hakim tingkat pertama kurang tepat dalam menentukan dasar hukum dengan menggunakan acuan Yurisprudensi Mahkamah Agung Republik Indonesia Nomor 3201K/Pdt/1984 dan Surat Edaran Mahkamah Agung Nomor 07 tahun 2012 (SEMA) yang dimana telah di revisi dengan Surat Edaran Mahkamah Agung (SEMA) Nomor 04 tahun 2014, kekuatan untuk melaksanakan parate eksekusi bukan di dasarkan atas suatu titel eksekutorial melainkan di dasarkan atas kuasa mutlak yang di berikan oleh si pemberi jaminan selaku debitor kepada si pemegang jaminan selaku kreditor dalam bentuk mandat atau karena telah di perjanjikan.

\section{DAFTAR PUSTAKA}

[1] Ahmad, A. (1996). Dimensi Hukum Islam Dalam Sistem Hukum Nasional. Jakarta: Gema Insani Press.

[2] Anshori, A. G. (2007). Peradilan Agama di Indonesia Pasca UU No. 3 Tahun 2006, Tentang Sejarah, Kedudukan \& Kewenangan. Yogyakarta: UII Press.

[3] Harahap, M. Y. (2009). Kedudukan Kewenangan dan Acara Peradilan Agama, UU No. 7 Tahun 1989. Jakarta: Sinar Grafika.

[4] Nurhasanah, N., \& Adam, P. (2017). Hukum Perbankan Syariah Konsep dan Regulasi. Jakarta: Sinar Grafika.

[5] Metokusuma, S. (2002). Hukum Acara Perdata Indonesia, Yogyakarta:. Yogyakarta: Liberty. 